\title{
COLLABORATIVE LEARNING THROUGH LESSON STUDY IN PMRI TRAINING FOR PRIMARY SCHOOL PRE-SERVICE TEACHER: THE SIMULATION OF POLYGON MATTER
}

\author{
Anna Fauziah ${ }^{1,2}$, Ratu Ilma Indra Putri ${ }^{2 *}$, Zulkardi $^{2}$ \\ ${ }^{1}$ STKIP PGRI Lubuklinggau, Indonesia \\ ${ }^{2}$ Universitas Sriwijaya, Indonesia
}

\section{Article Info \\ Article history: \\ Received Oct 31, 2020 \\ Revised July 25, 2021 \\ Accepted July 27, 2021}

\section{Keywords:}

Collaborative Learning,

Lesson Study,

PMRI,

Polygon

\begin{abstract}
Collaborative learning through lesson study has become one of the promising methods for improving the quality of education and improving teachers' quality, likewise with the PMRI approach. The combination of the two in the training for primary school pre-service teachers, specifically in the second simulation session, was observed and reported. This article aims to describe the collaboration process in the second session of the simulations about polygon learning at PMRI training for primary school pre-service teachers. A design research method of the development type was used in this study, only at the preliminary and development or prototyping phase. The research subjects are students of Primary School Pre-service Teachers of Sriwijaya University that consisted of eight students for the small group and 32 students for the field test. Data was collected through documentation, observation, and field notes. The result showed that there were good collaboration occurs between researcher-lecturer, lecturer-student, and between students at the plan-do-see-redesign stage of the lesson study.
\end{abstract}

This is an open access article under the CC BY-SA license.

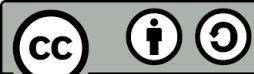

\section{Corresponding Author:}

Ratu Ilma Indra Putri,

Departement of Mathematics Education,

Universitas Sriwijaya

Jl. Masjid Al Gazali, Bukit Lama, Ilir Bar. I, Palembang, South Sumatra 30128, Indonesia

Email: ratuilma@unsri.ac.id

\section{How to Cite:}

Fauziah, A., Putri, R. I. I., \& Zulkardi, Z. (2022). Collaborative learning through lesson study in PMRI training for primary school pre-service teacher: the simulation of polygon matter. Infinity, 11(1), 1-16.

\section{INTRODUCTION}

Various studies have been developed on collaborative learning and positively impacted at all levels of education. Lesson study contributed positively to the teacher's professional development program (Chong \& Kong, 2012; Lawrence \& Chong, 2010). The development of lesson study for teachers has also changed the poses of learning, from teacher-centered to student-centered (Kusumah \& Nurhasanah, 2017). Lesson study has also improved the performance and confidence of pre-service teachers (Kanellopoulou \& Darra, 
2019). Besides, lesson study has also helped improve students' mathematical ability; one is reasoning ability (Octriana et al., 2019). This impact because collaborative learning provides an opportunity for each learner to learn. Collaborative learning plays an important role in creating quality learning. However, not all learners, especially in higher education, collaborate effectively (Fransen et al., 2011). Most students prioritize completing assignments rather than teamwork. For this reason, efforts are needed to design learning that makes students interact and collaborate effectively. So, lecturers play an essential role in designing and implementing in the class (De Hei et al., 2014).

Lesson study is a learning system that uses collaborative learning at each stage. In lesson study, teachers collaborate continuously to produce better education through planning, application, and implementation in class, observing, and reporting the results (Putri \& Zulkardi, 2019). Lesson study has four stages, namely (1) The planning stage, aims to produce a learning device design; (2) The do stage, aims to carry out the learning that has been designed at the planning stage; (3) The see stage which aims to find the strengths and weaknesses of the learning implementation, and (4) The redesign stage which aims to make improvements to the learning design if there is anything that needs to be improved based on the results at the before step. Thus, the lesson study cycle begins with the teacher collaborating in selecting topics, planning and preparing lessons, then one teacher conducts learning and the other teachers observe the class, continue with the teachers discussing the results of their observations and reflecting, and finally re-planning the lesson. The four stages of the lesson study run as a cycle and require collaboration between each party involved.

This research is part of developing Pendidikan Matematika Realistik Indonesia (PMRI) learning environments through lesson studies developed by researchers (Fauziah et al., 2020). So, PMRI was used as a learning approach in this study. PMRI itself is the Indonesian version of RME, which is a learning innovation that has reformed education in Indonesia (Hadi, 2015) and has been widely used in teacher candidates (Zulkardi, 2002) and teacher professional development programs (Ekawati \& Kohar, 2017; Putri et al., 2015). PMRI using the real context as a starting point for learning (Zulkardi \& Putri, 2019). PMRI is developed on three basic principles, namely (a) Guided reinvention and progressive mathematization; (b) Didactical phenomenology; and (c) Self-developed models (Gravemeijer, 1994).

PMRI has five characteristics, namely (1) using the real world context as the starting point of learning, (2) using the model as a bridge between the abstract and the real world, (3) using the students' own results or strategies, (4) the interaction as essential elements in learning mathematics and (5) the connection of each learning strand (Zulkardi \& Putri, 2019). As for the principles, Van den Heuvel-Panhuizen and Drijvers (2014) explain that each principle reflects every characteristic of PMRI, which includes activity principle, reality principle, level principle, intertwinment principle, interactivity principle, and guidance principle.

However, this report only focuses on discussing the process of collaboration through lesson study (plan-do-see-redesign) in the second simulation session, namely on polygon learning. A polygon is a closed plane figure bounded by straight line segments as sides. Polygon is a part of circumference and area of plane materials in grade 4 of primary school in the K-13 curriculum. Students will be asked to analyze the properties of polygons and identify regular polygon and irregular polygons. Several studies show that there are still difficulties faced by primary school students when learning about the polygon concept (Bernabeu et al., 2018; Chiphambo \& Feza, 2020; Fisher et al., 2013). Primary school students need scaffolding that facilitates them to learn about polygon. This technique can increase student involvement, focus students' attention and exploration, and encourage students' "sense-making" (Alfieri et al., 2011; Fisher et al., 2013; Honomichl \& Chen, 2012). 
Because geometry, especially polygons, is all around us, PMRI and collaborative methods are expected to help improve student understanding. However, this research was applied to primary school pre-service teachers, not to primary school students, to develop their ability to PMRI and collaborative methods, which are expected to be used when they become teachers in the future. Thus, this research report aims to discover the collaborative process in developing the PMRI learning environment through lesson study in primary school preservice teachers for the second simulation session: The Polygon matter. The collaboration process that will be reported is the collaboration process between lecturers and researchers, between students, and between lecturers, researchers, and students.

\section{METHOD}

This study used design research with the type of development study at the preliminary and prototyping stages (Plomp, 2013). The research subjects are students of Primary School Pre-service Teachers of Sriwijaya University. The research was preceded by curriculum analysis and the design of polygon learning materials conducted by researchers and team teaching who are lecturers of primary school pre-service teacher education. The learning materials produced were validated through self-evaluation, expert review, and oneto-one. They were tested in a small group with eight students with mixed abilities consisting of two men and four women. During the small group, students were divided into two groups consisting of four people. Finally, a field test was conducted on 32 students comprised of four men and 28 women. Students at this stage are divided into eight groups consisting of four students with different abilities. Students who are subject to small groups differ in the field test. The collaborative process seen in this study was during preliminary, small group, and field tests.

The data was collected through documentation, observation, and field notes. Documentation was done in the form of photos, videos during the research process. Documentation and field notes were the findings during the one-to-one, small group, and field test stages. Observations were made using observation sheets which included remarks about how students worked individually and collaborated in learning, how students said the sentence, "please teach me" when they had difficulties, actively expressed opinions, showed enthusiasm, and concluded learning. The collected data was then analyzed qualitatively to describe each stage of the collaboration process. Observation sheets were analyzed descriptively based on student activities at the small group stage and field tests by processing the scores obtained on the observation sheet and determining the percentage for each component.

\section{RESULTS AND DISCUSSION}

\subsection{Results}

The collaborative process through lesson study in PMRI training has begun since the preliminary stage. A team consisting of a research team and two lecturers who are teamteaching, design the device. The research team used this first collaboration result in PMRI training through lesson study for primary school pre-service teachers in simulation sessions. The learning devices are PMRI learning materials with polygon topics consisting of learning implementation plans, student worksheet I, student worksheet II, and teacher's instructions that were predicting student activities and answers. Student worksheet I contain a sharing task, and student worksheet II has the jumping task. This stage is the first stage of the lesson 
study. The context generated through this collaboration is the "Pentagon Building" for sharing tasks and "The Dome of Shakhrah" for jumping tasks. After the device has been designed and validated, the materials are used in a learning simulation session in class through two stages: small group and field test. During the lesson, one PGSD lecturer was appointed as a model lecturer while the research team and other lecturers acted as observers.

In the simulation session in class, the learning phase in small groups and field tests, is the "do" stage in lesson study. Before the learning process begins, the model lecturer conditions the participant's seat to form the letter "U". Learning continues with the model lecturer explaining the learning process that will take place. If there are students who have difficulties working on student worksheets, they can ask other students for help by first saying, please teach me, and that students have to explain. Furthermore, the model lecturer conveyed apperception related to polygon matter. Then the model lecturer gives student worksheet I, which contains sharing tasks for students to do individually. The model lecturer and observers go around observing every activity carried out by students. When a model lecturer encounters a student who is having difficulty, the lecturer directs the student to ask his friend.

In student worksheet I, students are asked to find and redraw the polygon in the pentagon building that is photographed from above, as shown in Figure 1.

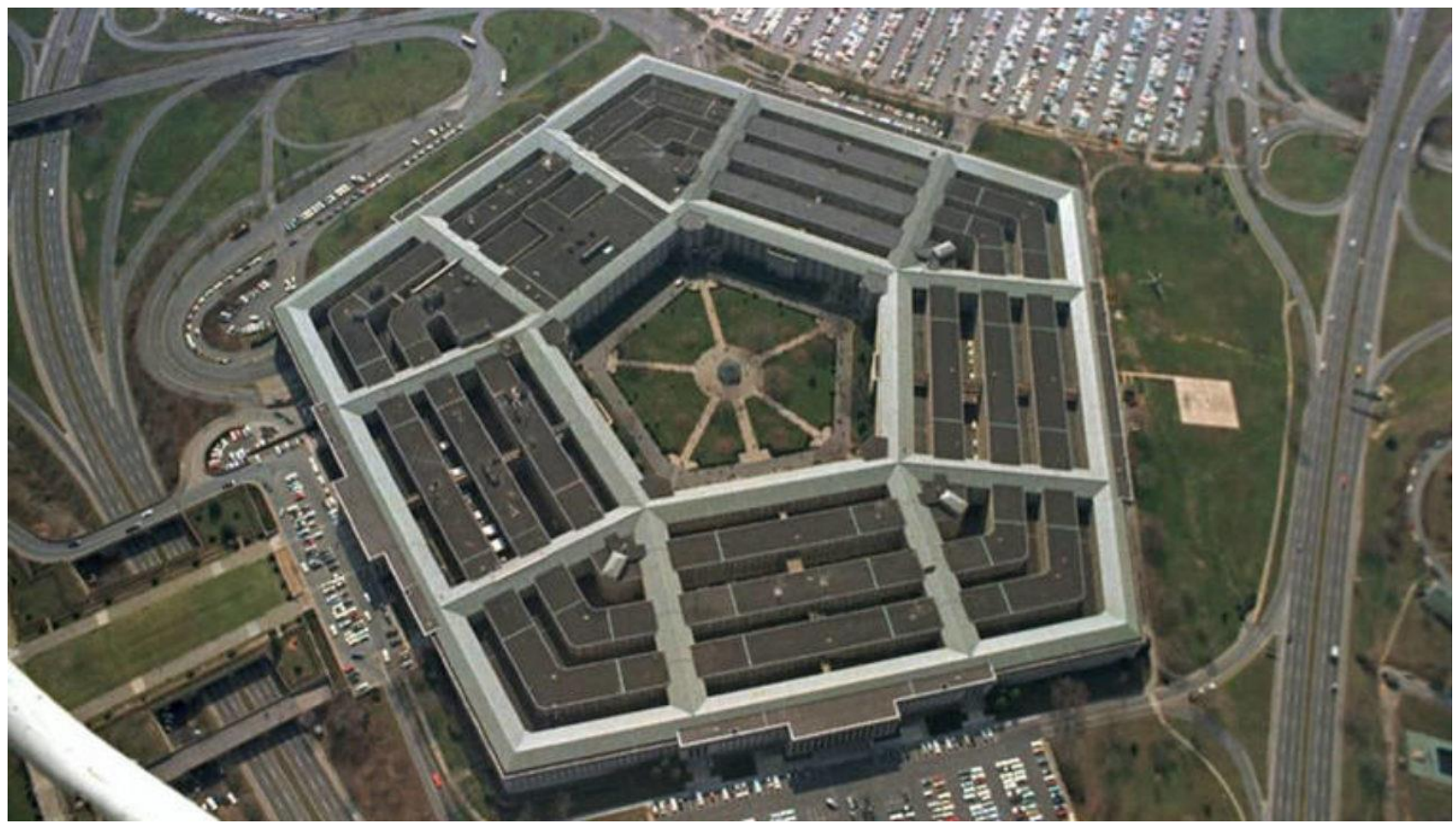

Figure 1. The Pentagon building is used as sharing task

Then name the polygon and give reasons related to the naming of the polygon. This problem is classified as a sharing task. Students who have low abilities are predicted can do it. Based on the researcher's and observers' observations, most students answered this problem well, both at the small group and field test. Following is the students' answer in the small group phase in Figure 2. 

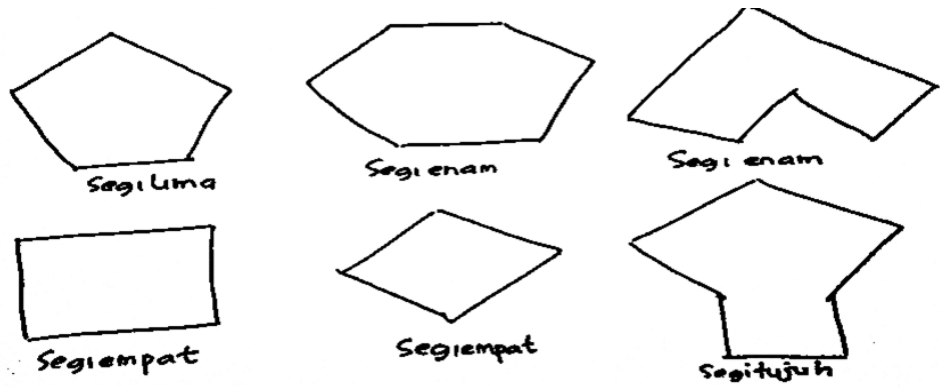

Translate version:

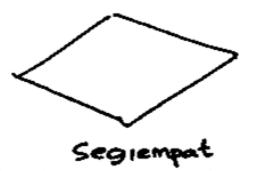

$$
\begin{array}{ccc}
\text { Pentagon } & \text { Hexagon } & \text { Hexagon } \\
\text { Rectangle } & \text { Quadrilateral } & \text { Heptagon }
\end{array}
$$

Figure 2. Students' answer on student worksheet I

In Figure 2, students have been able to find several polygons found in the pentagon building. In the beginning, some students only found two polygons in the picture of the pentagon building, namely quadrilateral and pentagon. The observers saw a collaboration process between students who have not been able to with students who can answer well. Figure 3 shows the collaboration process that occurs between students.
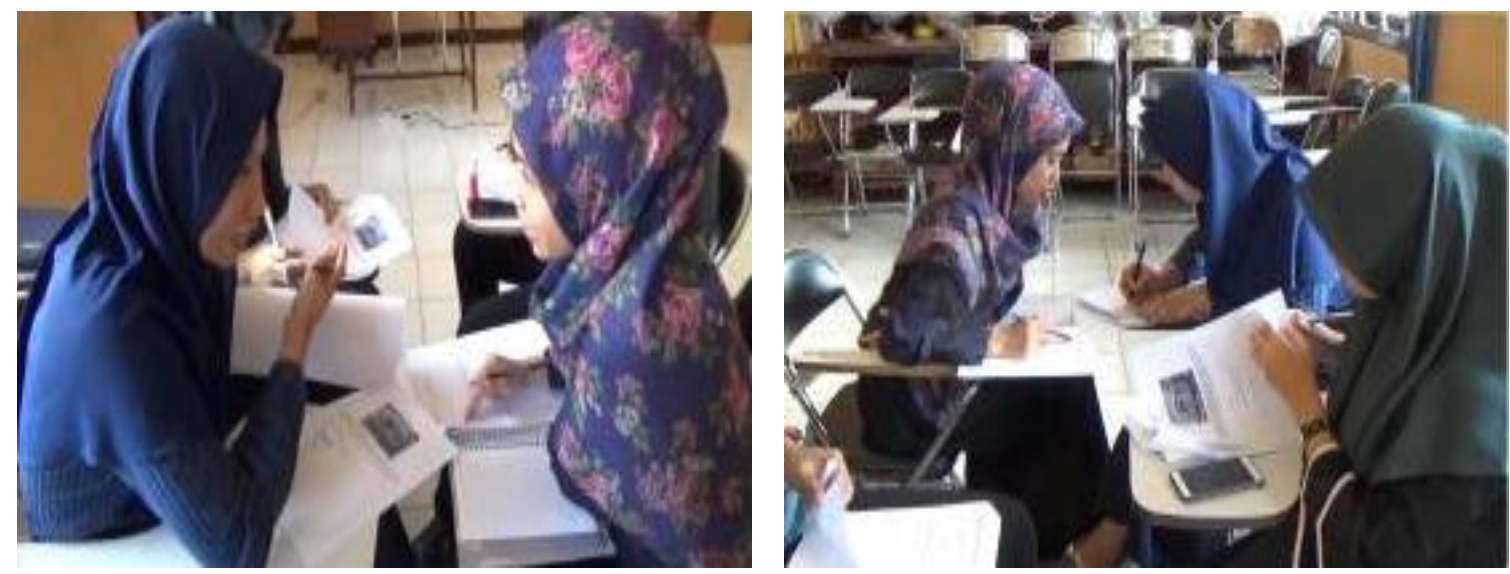

Figure 3. The collaboration process between students

In Figure 3, a student asked her friend associated with the problems that exist in the worksheet. The following dialogue between that two students:

Student 1 : Masayu, please teach me. How do you find other shapes besides quadrilateral and pentagon? Because I only saw two polygons, pentagon, and quadrilateral.

Student 2 : Uhm, try to imagine a polygon's shape that occurs if you combine several polygons. It will be easier if you redraw the pentagon building and observe it again correctly.

Student 1 : Oo yeah, all right, thanks for the instructions.

After a while, the underprivileged students managed to find another plane. 
In the next question, the researcher asked students to find two polygons that have the same name but have differences and asked students to find these differences. The following is the students' answers, as shown in Figure 4.

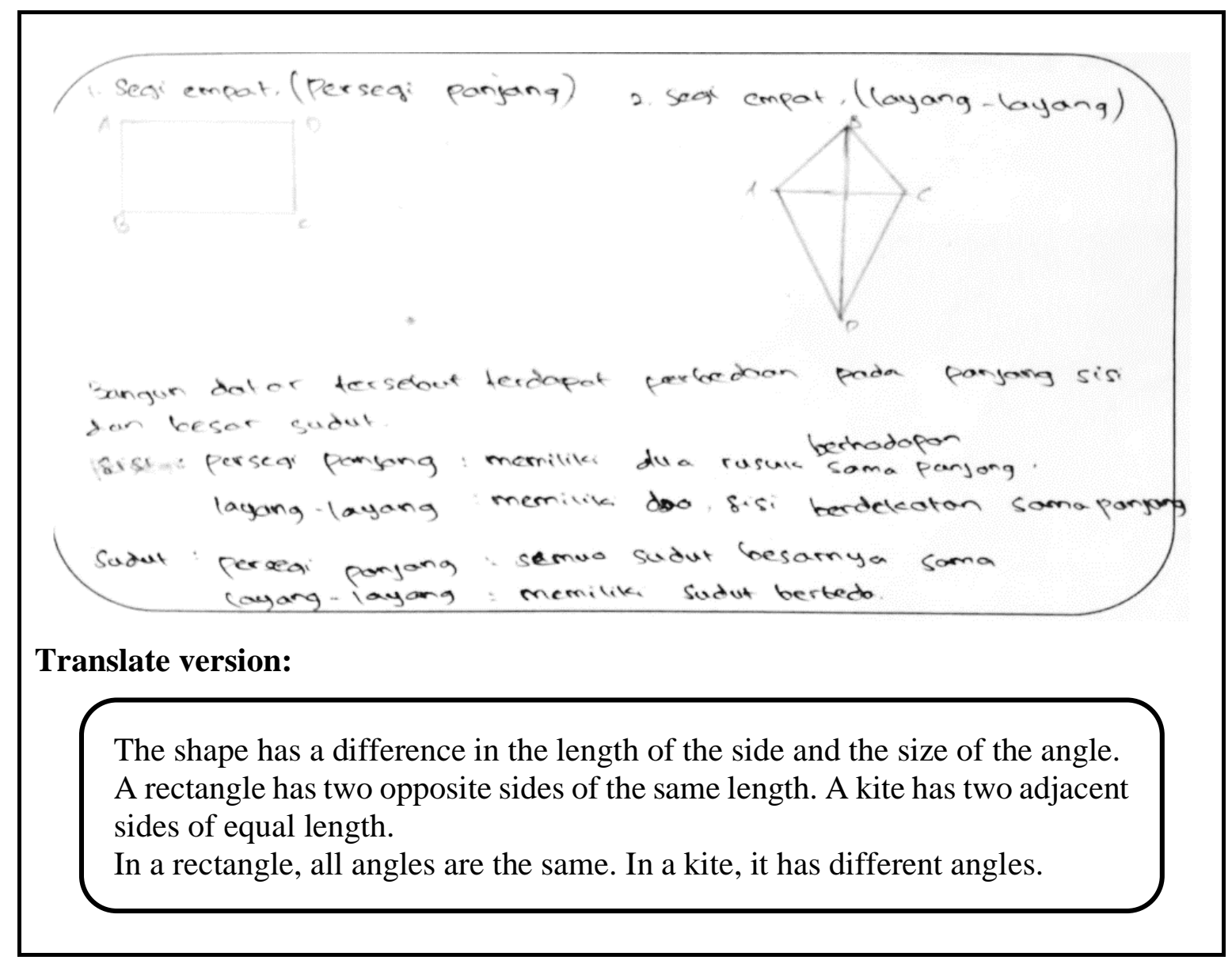

Figure 4. Students' answer on student worksheet I

In Figure 4, students can find two shapes with the same name, namely a rectangle and a kite, both of which are part of a quadrilateral. The next question is that students are asked to find two shapes that are the same but have differences, following the student's answers in Figure 5 and Figure 6. 


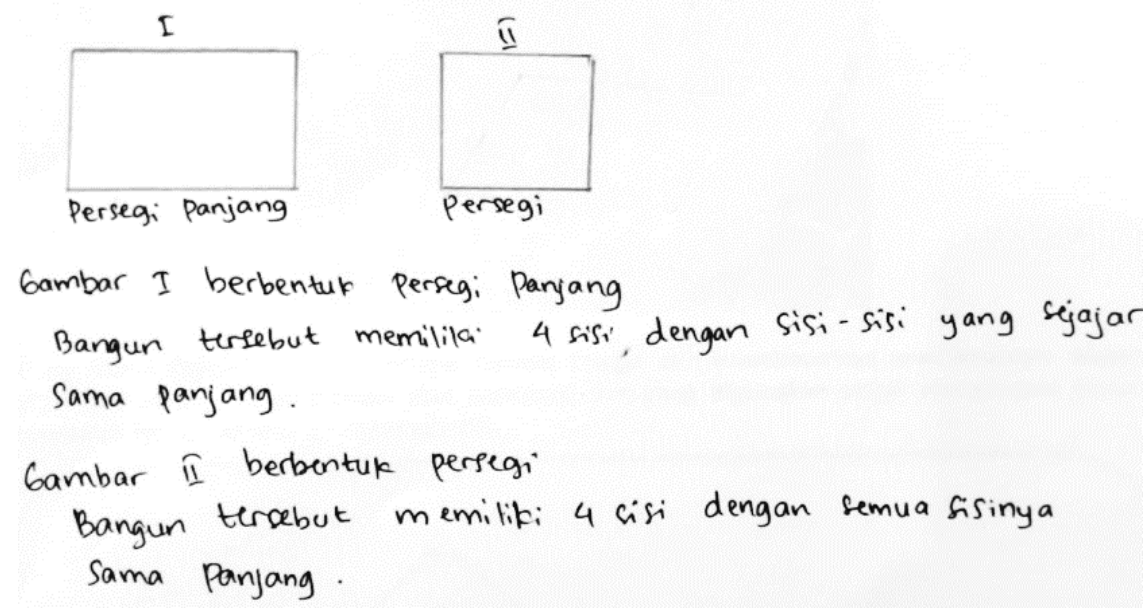

Translate version:

Figure 1. Rectangle

The shape has four sides where the parallel sides are equal.

Figure 2. Square

The shape has four sides where all the sides are equal.

Figure 5. Students' answer on student worksheet I

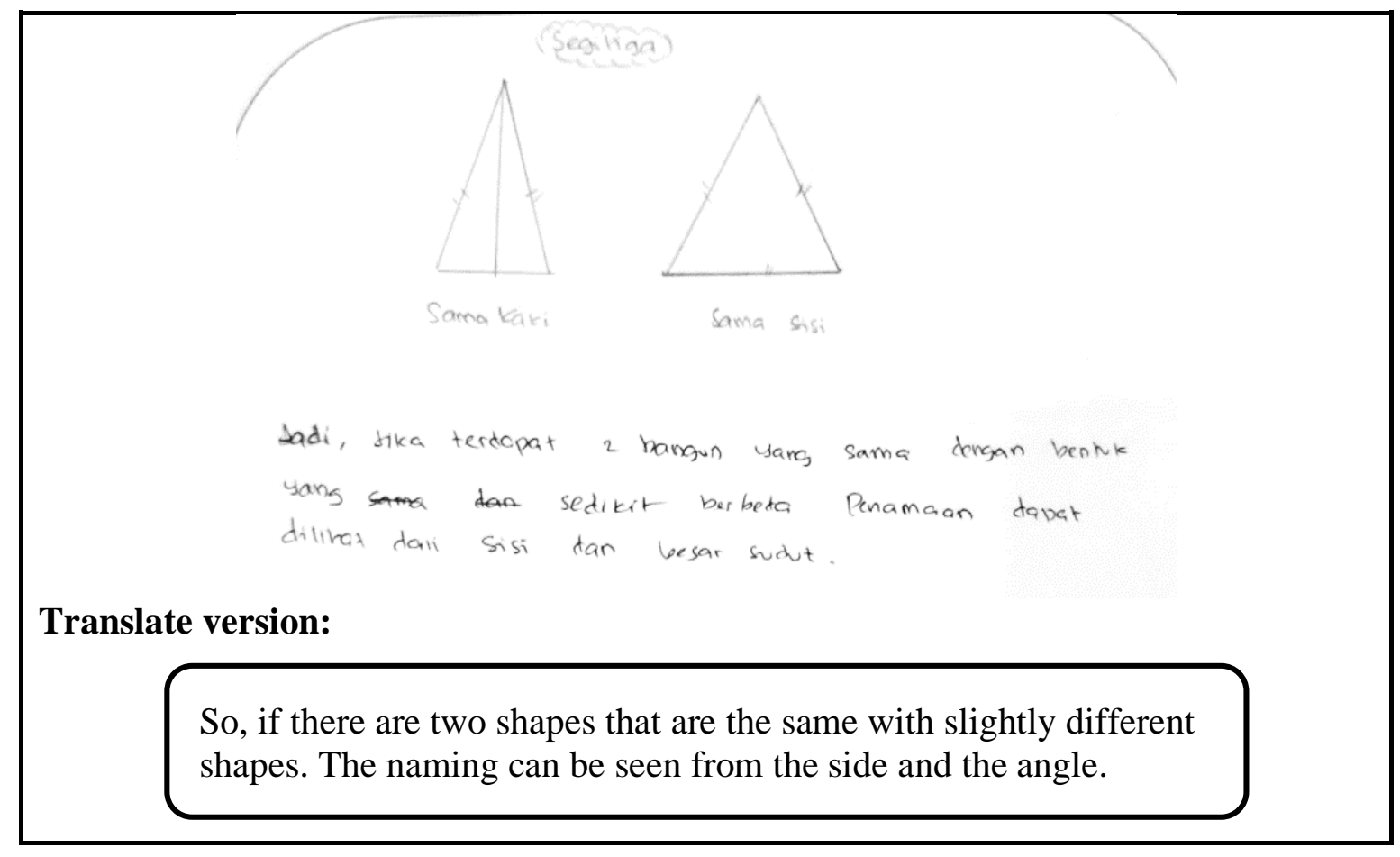

Figure 6. Students' answer on Student Worksheet I 
Students have been able to find two shapes that both the same name but are different, namely a square and a rectangle which is part of a quadrilateral and an isosceles triangle and an equilateral triangle which is a triangle. Next, students are asked to provide conclusions from some of the problems above. Following are the answers of students who conclude the problem, as shown in Figure 7.

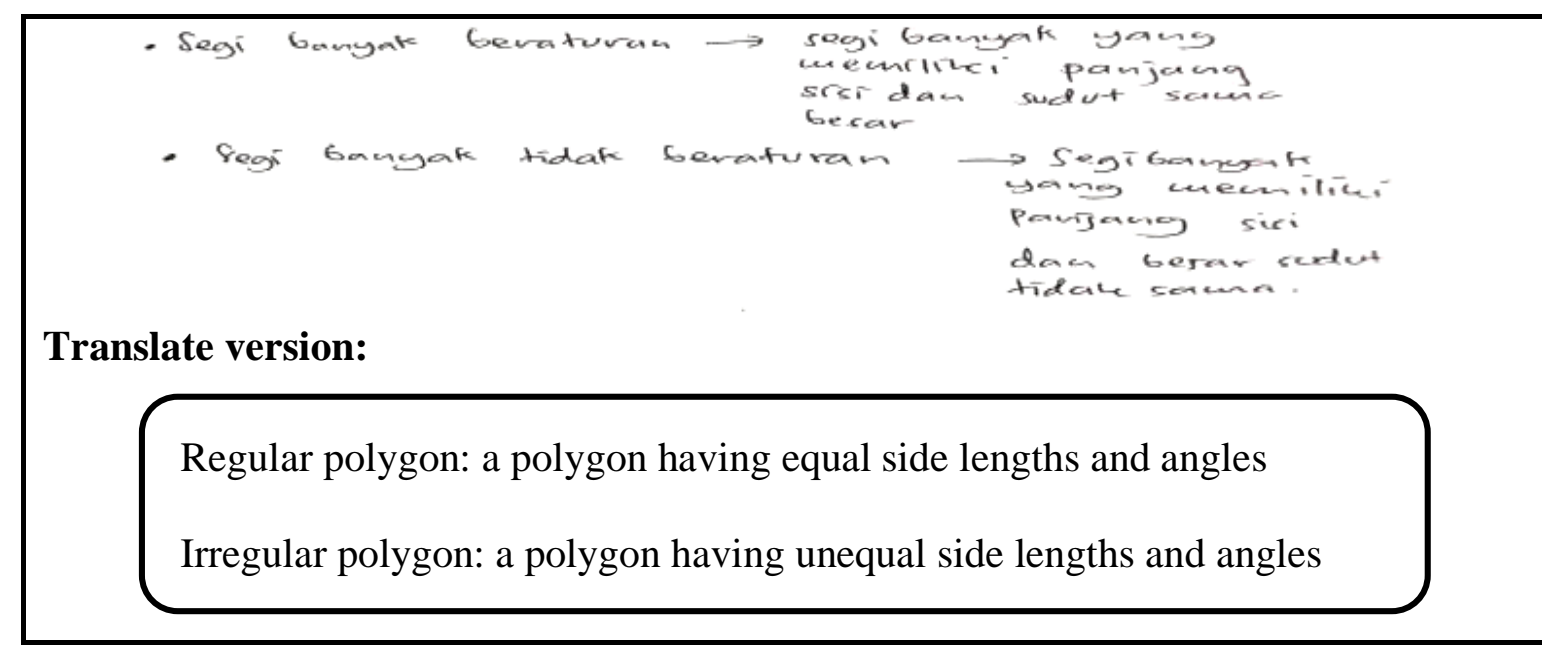

Figure 7. Students' answer on student worksheet I

Learning continues with the model lecturer giving student worksheet II which contains a jumping task. In student worksheet II, the Dome of Shakhrah used as a context to define a polygon, in this case, the octagon. It is a golden-domed building located in the middle of the Al Aqsa Mosque complex in Palestine, as shown in Figure 8.

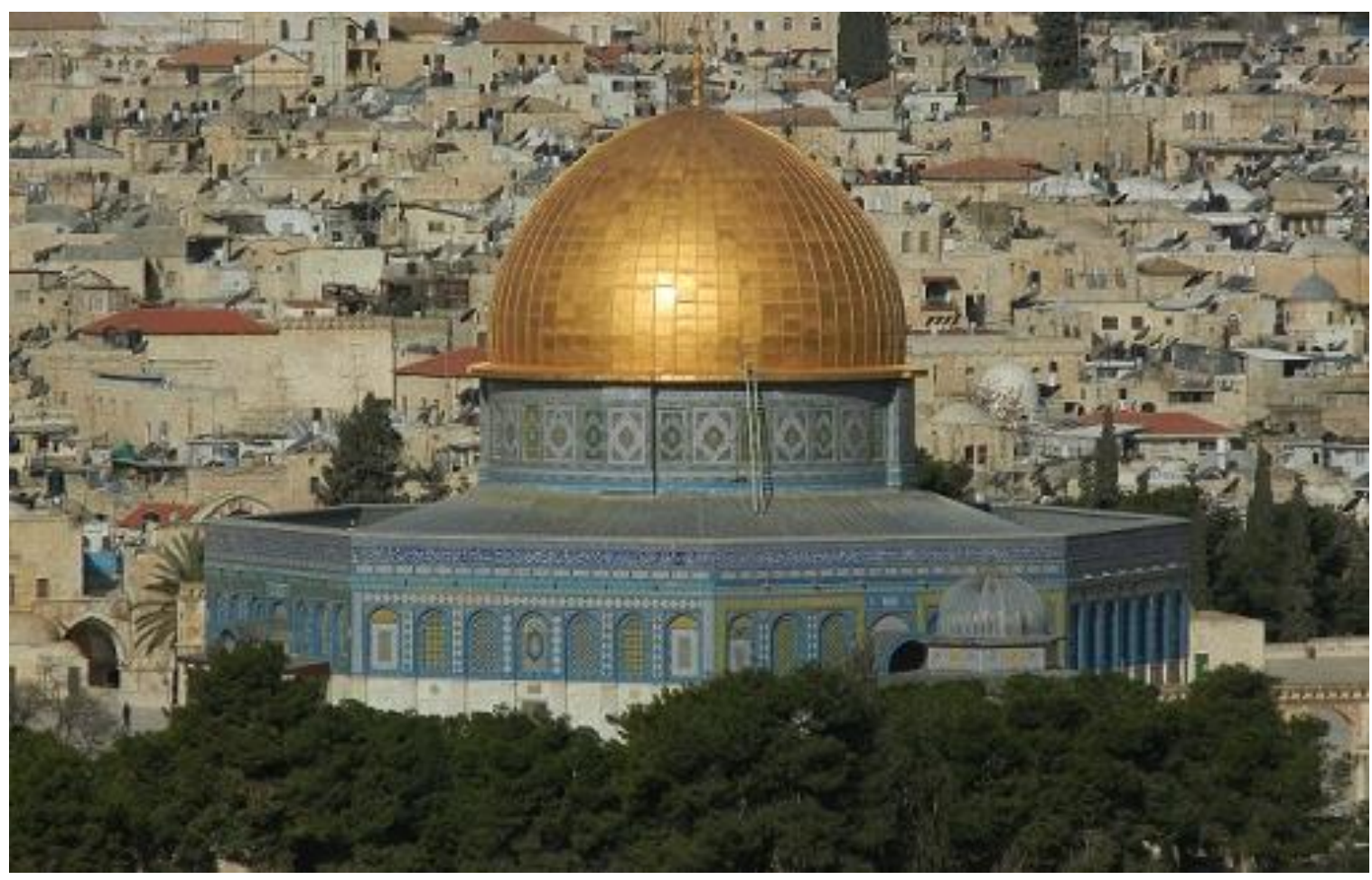

Figure 8. The Dome of Shakhrah is used as jumping task 
Students are asked to find the polygon contained in the picture and draw as many other polygons as they can from it. When finding the polygon, only a few students are confused because a dome covers part of the polygon side. Students have been able to find that polygons found in the dome of the rock are octagon and rectangle as shown in Figure 9.

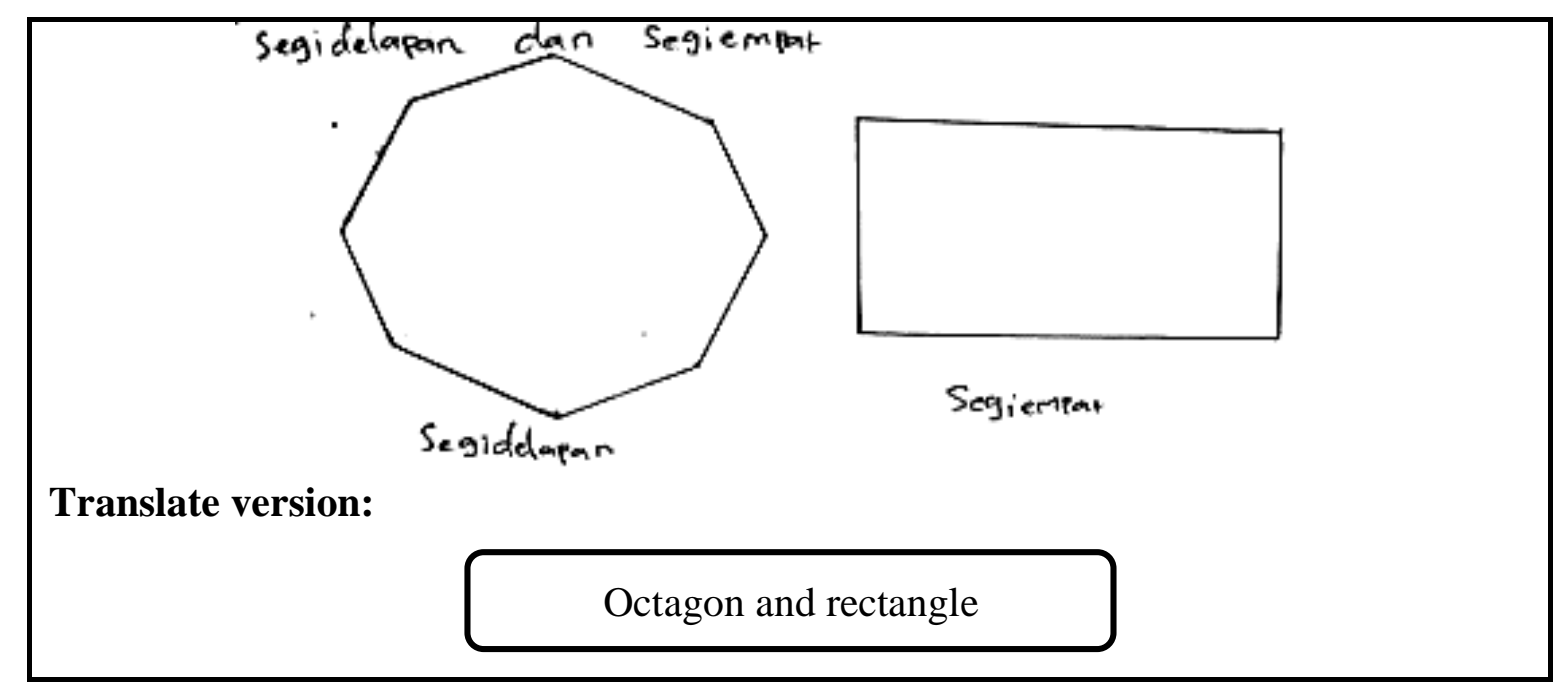

Figure 9. Students' answer on student worksheet II

However, when asked to draw a lot of other things found in a lot that was found, there were quite a lot of difficulties. Most students find a different number of polygons, and only a few students find heptagon, as shown in Figure 10 and Figure 11.

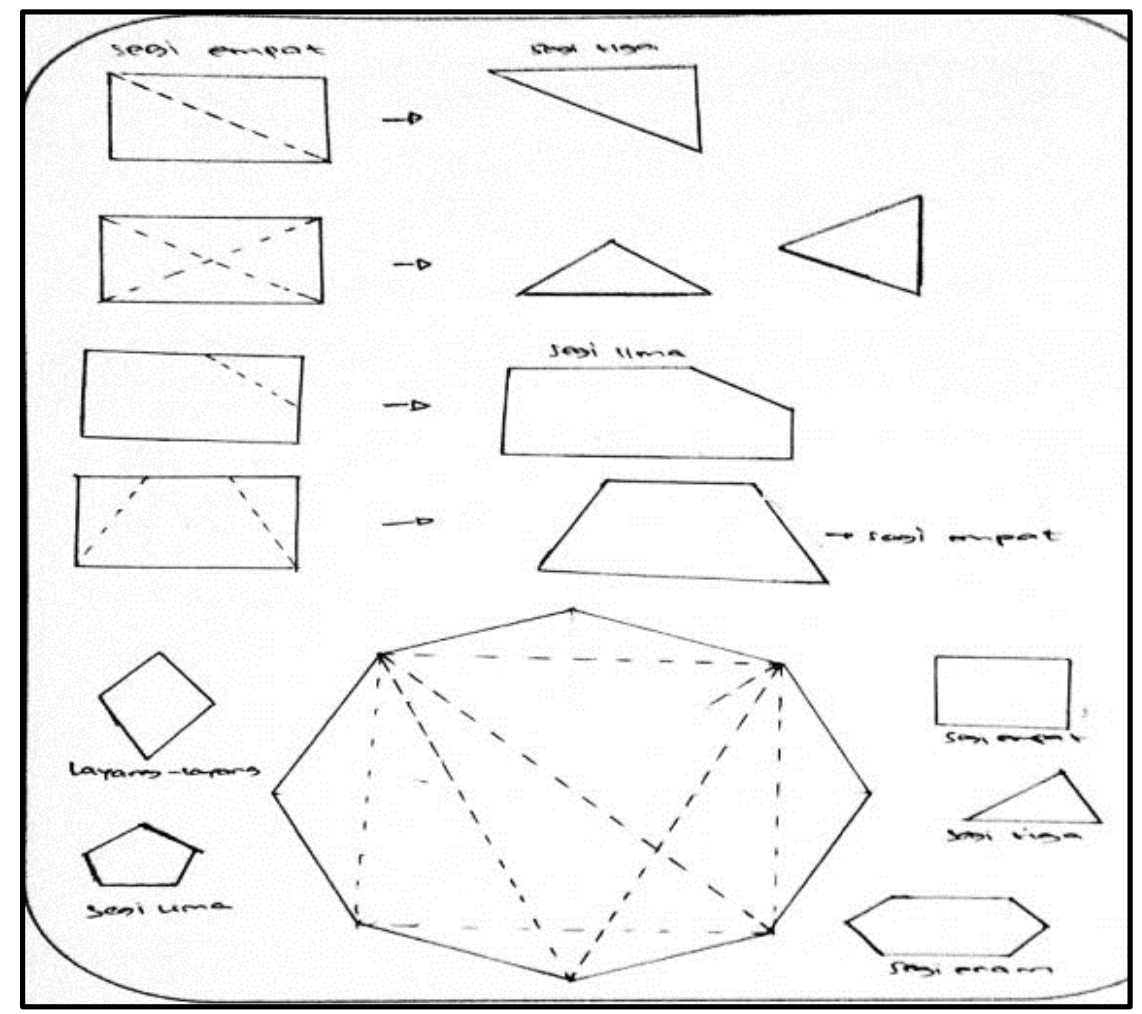

Figure 10. Students' answer on student worksheet II 


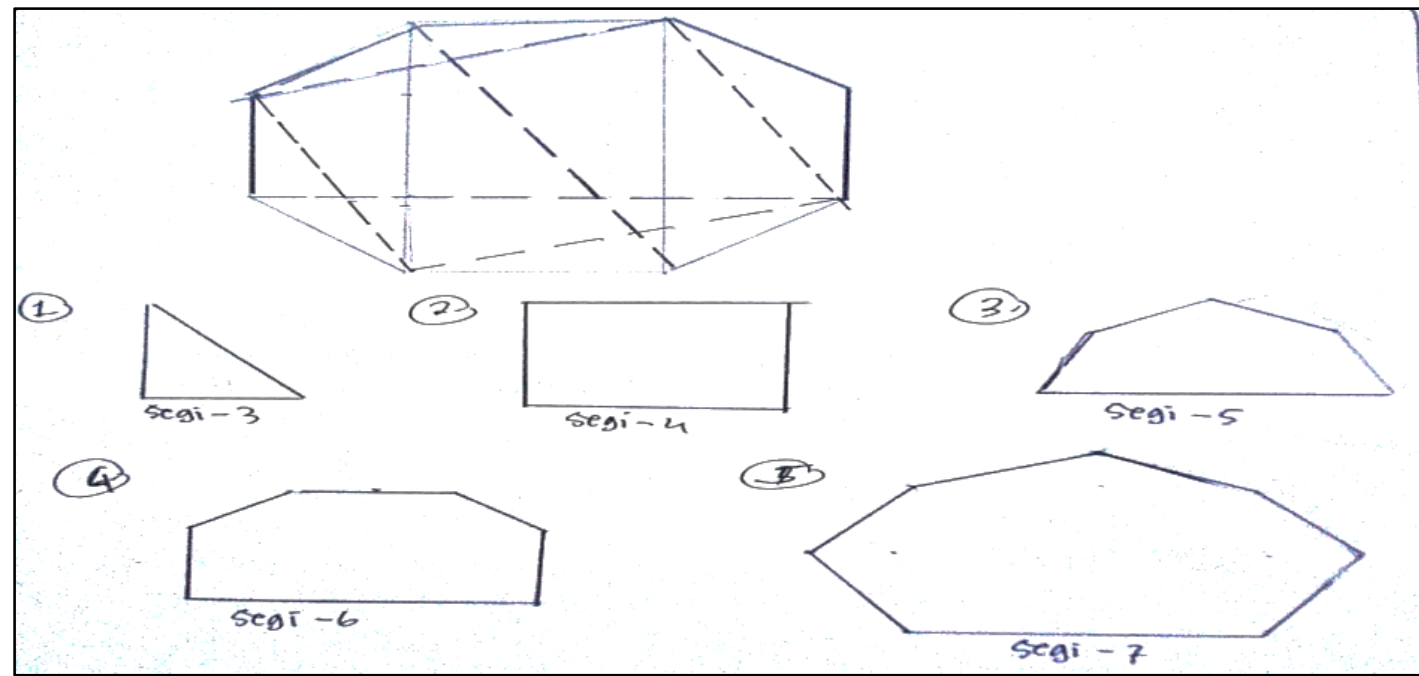

Figure 11. Students' answer on student worksheet II

In Figure 10, students only found a hexagonal and in Figure 11, students were able to find a heptagonal. Figure 10 and Figure 11 are the results of student answers at the field test stage. Students get polygons in the polygon by multiplying lines from one vertex to another vertex. The observers observed that this result was also obtained through a good collaboration process between students. Communication and discussion in groups make students able to draw a heptagon in the octagon. At the end of the lesson, the model lecturer asks the student who was initially struggling to explain the answers. So, the student gained confidence because he was able to answer the problem well.

Based on observations, the collaborative learning component has appeared well during this much learning simulation. The following are the results of the calculation of the observation sheet during learning as shown in Table 1.

Table 1. The result of observation during learning

\begin{tabular}{lc}
\hline \multicolumn{1}{c}{ Activity } & Percentage \\
\hline Students work on each worksheet individually & $100 \%$ \\
Students collaborate in learning & $85 \%$ \\
Students say the sentence "please teach me" when asking for help from friends & $90 \%$ \\
Students actively express opinions & $80 \%$ \\
Students show enthusiasm in learning & $85 \%$ \\
Students conclude learning & $85 \%$ \\
\hline \multicolumn{1}{c}{ Average } & $87.5 \%$ \\
\hline
\end{tabular}

Table 1 shows that $100 \%$ have worked on worksheets individually, $85 \%$ of students have collaborated with other students during learning, $90 \%$ of students have said sentences please teach me when they ask their friends for help, $80 \%$ of students actively express opinions during discussions Together with lecturers, $85 \%$ of students showed enthusiasm in learning and $85 \%$ of students were able to conclude learning as a result of collaboration. Thus, the average student has carried out a very good collaboration process between them, which is equal to $87.5 \%$. 
After the learning process ends, the research team, teaching team, and students reflect the learning that has occurred. This reflection session in the lesson study cycle is the see stage. Students participate in the reflection process as part of the student learning process in PMRI training through lesson study. The model lecturer begins the process of reflection by giving impressions, experiences, and obstacles encountered when conducting learning. The model lecturer said that this was the first time she had done collaborative learning in her class and felt something different. Lecturer as model teacher, facilitate, motivate and direct students to collaborate in learning. The lecturer motivates students who have difficulty saying sentences, "please teach me" to their friends who have been able to solve problems. This makes students unselfish by teaching each other to their friends, even though worksheets are given individually.

The research team, as an observer, explains the activities of the students we observe. Researchers also provide input on education that takes place in the right language to offend the model lecturers. Students who act as subjects also give their impressions and opinions on the learning that has taken place. Thus, at this stage, the collaborative process has also occurred between the research team, the teaching team, and students to produce learning well. The next step is a redesign, and based on the results of reflection, there are improvements to the lesson plans, student worksheets, and teacher's instruction.

\subsection{Discussion}

The first collaboration occurred between researchers and lecturers in the primary school teacher education study program who were the research team teaching. Together with lecturers, researchers designed PMRI learning tools through lesson studies with the topic of polygons, which were then validated before being used in learning. Researchers and lecturers work together in determining the context that will be used in the student worksheets. Choosing the right context is very important in PMRI learning as a starting point (Gravemeijer \& Doorman, 1999; Widjaja et al., 2010). In addition to make it easier for students to understand the material (Fauziah et al., 2017, 2019; Risdiyanti et al., 2019), the context also plays a role in stimulating students to think, communicate, and collaborate (Asari, 2017). This first collaboration of lesson study that requires lecturers and researchers to make instructional learning and choose strategies in teaching, have made lecturers more confident in teaching. This is consistent with the research results that have been carried out relating to lecturers' collaborative learning and self-confidence (Chong \& Kong, 2012).

The second collaboration is the collaboration that occurs between students and lecturers, as well as between students. At the time of learning using this collaborative method, the lecturer arranges student seats to be shaped like the letter "U". It is intended that the model lecturer can accurately monitor each activity carried out by students, and students can see each other (Mustadi, 2014). The lecturer directs students to ask their friends if they have difficulty working on student worksheets. According to collaborative learning, this is a method that encourages and invites students to work together in doing the learning task (De Hei et al., 2014). This has been seen in the results of research, some students have asked their friends when they encounter difficulties and are finally able to answer questions after hearing explanations from their friends. These results indicate that good collaboration has occurred between the two students. The ability to hear from others becomes an essential element in building dialogue and collaboration (Saito et al., 2008). The sentence, please teach me, is also very good to continue to be cultivated among students. Students are not used to this sentence when asking their friends. This result suggests that the lesson study has taught students of the philosophy of education by Indonesian culture (Mustadi, 2014). Especially when students work on student worksheet II which is a jumping task, the process 
of collaborating with each other between students is more common. It is estimated that many students find it challenging to answer problems because jumping task consists of a more difficult task than sharing task (Asari, 2017; Hobri et al., 2020). Thus, this second collaboration have a positive impact on learning motivaton and student learning outcomes (De Hei et al., 2014). Students have been able to solve problems on the worksheet through dialogue and collaboration between them.

The third collaboration occurs between students, lecturers and researchers when reflecting after the end of the lesson. The reflection process aims to evaluate, find weaknesses and strengths of the learning process that has taken place. This stage is a crucial component in lesson study (Wessels, 2018). The model teacher initiated the discussion by conveying the impressions experienced during the lesson and then continued with the delivery from the observers. Criticisms and suggestions are given wisely without cornering the teacher for future improvements. Conversely, those who are criticized must be able to receive input from the obeservers for further enhancement of learning. Based on input from the discussion at this stage, learning can be redesign so that further learning can be better. Thus, good results on all three collaborations show that collaborative learning through lesson study is recommended to be carried out in classes in tertiary institutions.

\section{CONCLUSION}

Collaborative learning has a positive impact on the learning process of primary school pre-service teacher students. At the time of planning, the collaborative approach resulted in a PMRI learning device in lesson plan, students' worksheets and teacher's instruction implemented in the simulation session. The learning process at the time of simulation, both at the small group stage and the field test, also shows a good collaboration between students to complete the given assignment. The average observation score obtained during learning is $87.5 \%$, which indicates that there has been good collaboration during the learning process. Finally, it also shows effective collaboration between researchers, model lecturers, and students to provide helpful input for polygon learning during the reflection.

\section{ACKNOWLEDGEMENTS}

The authors wish to express their gratitude to the Public Service Agency of Universitas Sriwijaya, for supporting and funding this research grant under contract number SP DIPA-023.17.2.677515/2020, revision 01, On March 16, 2020. In accordance with the Rector's Decree Number: 0687/UN9/SK.BUK.KP/2020, On July 15, 2020. The Head of the research project is Zulkardi.

\section{REFERENCES}

Alfieri, L., Brooks, P. J., Aldrich, N. J., \& Tenenbaum, H. R. (2011). Does discovery-based instruction enhance learning? Journal of Educational Psychology, 103(1), 1-18. https://doi.org/10.1037/a0021017

Asari, S. (2017). Sharing and jumping task in collaborative teaching and learning process. DIDAKTIKA: Jurnal Pemikiran Pendidikan, 23(2), 184-188. https://doi.org/10.30587/didaktika.v23i2.28 
Bernabeu, M., Moreno, M., \& Llinares, S. (2018). Primary school children's (9 year olds') understanding of quadrilaterals. In Proceedings of the 42nd Conference of the International Group for the Psychology of Mathematics Education, Umea, Sweden.

Chiphambo, S. M., \& Feza, N. N. (2020). Polygon pieces: Tools to address students' alternative conceptions and misunderstandings when learning of geometry. International Journal, 76(7), 191-208. https://doi.org/10.21506/j.ponte.2020.7.15

Chong, W. H., \& Kong, C. A. (2012). Teacher collaborative learning and teacher selfefficacy: The case of lesson study. The journal of experimental education, 80(3), 263-283. https://doi.org/10.1080/00220973.2011.596854

De Hei, M. S. A., Strijbos, J.-W., Sjoer, E., \& Admiraal, W. (2014). Collaborative learning in higher education: lecturers' practices and beliefs. Research Papers in Education, 30(2), 232-247. https://doi.org/10.1080/02671522.2014.908407

Ekawati, R., \& Kohar, A. W. (2017). Innovative teacher professional development within PMRI in Indonesia. International Journal of Innovation in Science and Mathematics Education, 24(5).

Fauziah, A., Putri, R., Zulkardi, Z., \& Somakim, S. (2017). Primary school student teachers' perception to Pendidikan Matematika Realistik Indonesia (PMRI) instruction. Journal of Physics: Conference Series, 943(1), 012044. https://doi.org/10.1088/1742-6596/943/1/012044

Fauziah, A., Putri, R., Zulkardi, Z., \& Somakim, S. (2019). The Roster context in angle learning for Primary School pre-service teachers. Journal of Physics: Conference Series, 1188(1), 012058. https://doi.org/10.1088/1742-6596/1188/1/012058

Fauziah, A., Putri, R. I. I., Zulkardi, Z., \& Somakim, S. (2020). Developing PMRI learning environment through lesson study for pre-service primary school teacher. Journal on Mathematics Education, 11(2), 193-208. https://doi.org/10.22342/jme.11.2.10914.193-208

Fisher, K. R., Hirsh-Pasek, K., Newcombe, N., \& Golinkoff, R. M. (2013). Taking shape: Supporting preschoolers' acquisition of geometric knowledge through guided play. Child development, 84(6), 1872-1878. https://doi.org/10.1111/cdev.12091

Fransen, J., Kirschner, P. A., \& Erkens, G. (2011). Mediating team effectiveness in the context of collaborative learning: The importance of team and task awareness. Computers in human Behavior, 27(3), 1103-1113. https://doi.org/10.1016/j.chb.2010.05.017

Gravemeijer, K., \& Doorman, M. (1999). Context problems in realistic mathematics education: A calculus course as an example. Educational Studies in Mathematics, 39(1), 111-129. https://doi.org/10.1023/A:1003749919816

Gravemeijer, K. P. E. (1994). Developing realistic mathematics education. Utrecht: CDBeta Press.

Hadi, S. (2015). The mathematics education reform movement in Indonesia. In S. J. Cho (Ed.), Selected Regular Lectures from the 12th International Congress on Mathematical Education (pp. 253-267). Springer International Publishing. https://doi.org/10.1007/978-3-319-17187-6_15 
Hobri, H., Ummah, I. K., Yuliati, N., \& Dafik, D. (2020). The effect of jumping task based on creative problem solving on students' problem solving ability. International Journal of Instruction, 13(1), 387-406. https://doi.org/10.29333/iji.2020.13126a

Honomichl, R. D., \& Chen, Z. (2012). The role of guidance in children's discovery learning. Wiley Interdisciplinary Reviews: Cognitive Science, 3(6), 615-622. https://doi.org/10.1002/wcs.1199

Kanellopoulou, E.-M., \& Darra, M. (2019). The implementation of the lesson study in basic teacher education: A research review. Higher Education Studies, 9(3), 65-78. https://doi.org/10.5539/hes.v9n3p65

Kusumah, Y. S., \& Nurhasanah, F. (2017). The endless long-term program of mathematics teacher professional development in Indonesia. In B. Kaur \& C. Vistro-Yu (Eds.), Professional Development of Mathematics Teachers (pp. 33-45). Springer. https://doi.org/10.1007/978-981-10-2598-3_3

Lawrence, C. A., \& Chong, W. H. (2010). Teacher collaborative learning through the lesson study: Identifying pathways for instructional success in a Singapore high school. Asia Pacific Education Review, 11(4), 565-572. https://doi.org/10.1007/s12564-0109103-3

Mustadi, A. (2014). Fundamental school reform through lesson study for learning community (LSLC): A study of collaborative learning in Indonesia and Japan. In Proceeding International Conference on Fundamentals and Implementation of Education (ICFIE), Yogyakarta.

Octriana, I., Putri, R. I. I., \& Nurjannah, N. (2019). Penalaran matematis siswa dalam pembelajaran pola bilangan menggunakan PMRI dan LSLC. Jurnal Pendidikan Matematika, 13(2), 131-142. https://doi.org/10.22342/jpm.13.2.6714.131-142

Plomp, T. (2013). Educational design research: An introduction. In T. Plomp \& N. Nieveen (Eds.), Educational design research (pp. 10-51). SLO.

Putri, R. I. I., Dolk, M., \& Zulkardi, Z. (2015). Professional development of PMRI teachers for introducing social norms. Journal on Mathematics Education, 6(1), 11-19. https://doi.org/10.22342/jme.6.1.1900.11-19

Putri, R. I. I., \& Zulkardi, Z. (2019). Designing jumping task on percent using PMRI and collaborative learning. International Journal on Emerging Mathematics Education, 3(1), 105-116. https://doi.org/10.12928/ijeme.v3i1.12208

Risdiyanti, I., Prahmana, R. C. I., \& Shahrill, M. (2019). The learning trajectory of social arithmetic using an Indonesian traditional game. Ilkogretim Online, 18(4), 20942108. https://doi.org/10.17051/ilkonline.2019.639439

Saito, E., Hawe, P., Hadiprawiroc, S., \& Sukirman, S. (2008). Initiating education reform through lesson study at a university in Indonesia. Educational Action Research, 16(3), 391-406. https://doi.org/10.1080/09650790802260372

Van den Heuvel-Panhuizen, M., \& Drijvers, P. (2014). Realistic mathematics education. In S. Lerman (Ed.), Encyclopedia of mathematics education (pp. 521-525). Springer Dordrecht. https://doi.org/10.1007/978-94-007-4978-8

Wessels, H. (2018). Noticing in Pre-service Teacher Education: Research Lessons as a Context for Reflection on Learners' Mathematical Reasoning and Sense-Making. In 
Invited Lectures from the 13th International Congress on Mathematical Education, Cham. https://doi.org/10.1007/978-3-319-72170-5_41

Widjaja, W., Dolk, M., \& Fauzan, A. (2010). The role of contexts and teacher's questioning to enhance students' thinking. Journal of Science and Mathematics Education in Southeast Asia, 33(2), 168-186. http://hdl.handle.net/10536/DRO/DU:30048397

Zulkardi, Z. (2002). Developing a learning environment on realistic mathematics education for Indonesian student teachers. Doctoral dissertation. University of Twente, Enschede. Retrieved from https://repository.unsri.ac.id/871

Zulkardi, Z., \& Putri, R. I. I. (2019). New School Mathematics Curricula, PISA and PMRI in Indonesia. In C. P. Vistro-Yu \& T. L. Toh (Eds.), School Mathematics Curricula: Asian Perspectives and Glimpses of Reform (pp. 39-49). Springer Singapore. https://doi.org/10.1007/978-981-13-6312-2_3 
